\title{
Dissection of Signaling in Inflammation: Three Novel Inflammatory Regulators
}

\author{
Thorsten Berger, Mary E. Saunders, and TaK W. MaK \\ The Campbell Family Institute for Breast Cancer Research and Ontario Cancer Institute, University \\ Health Network, Toronto, Ontario M5G 2C1, Canada \\ Correspondence:tmak@uhnres.utoronto.ca
}

\begin{abstract}
Uncontrolled inflammation is a feature of autoimmune diseases and autoinflammatory syndromes and may promote tumorigenesis. Thus, identifying molecules that regulate the signaling pathways triggering, mediating, and suppressing inflammation could be helpful in developing new therapeutic approaches for these debilitating diseases. In this review, we present new information on three molecules with important roles in controlling inflammation: MALT1, Ariadne-2, and acetylcholine. We summarize our current state of knowledge of how these molecules function, and how they are involved in pathways of NF- $\mathrm{KB}$ activation or vagal nerve stimulation associated with inflammation.
\end{abstract}

Inflammation is a double-edged sword: essential for defense against incipient disease, but also harmful to the body if the response persists. Uncontrolled inflammation is a feature of autoimmune diseases and autoinflammatory syndromes, and evidence is accumulating that chronic inflammation sets up conditions that favor tumorigenesis. Thus, identifying molecules that regulate the signaling pathways initiating, mediating, and suppressing inflammation could be helpful in developing new therapeutic approaches for these debilitating diseases.

Signaling pathways triggered during a normal inflammatory response lead to the activation of numerous cell types mediating innate and adaptive immune responses. A key group of transcription factors involved in the activation and effector functions of many of these leukocytes is known as the NF- $\mathrm{kB}$ family. Two pathways (Fig. 1) lead to the activation of NF- $\mathrm{\kappa B}$ family members: the classical or canonical pathway and the alternative or noncanonical pathway (Gasparini and Feldmann 2012). In both cases, the resulting transcriptionally active NF- $\mathrm{\kappa B}$ molecule is a dimer consisting of a family member such as $\mathrm{p} 50$ or $\mathrm{p} 52$, each of which possesses a Rel homology domain (RHD), and a family member such as RelA (p65), RelB, or c-Rel, each of which possesses both an RHD domain and a transcription activation domain. Transcriptionally active NF$\mathrm{\kappa B}$ molecules initiate the transcription of specific sets of target genes that trigger not only the production of proinflammatory cytokines but also the recruitment, proliferation, and activation of innate and adaptive leukocytes. Tellingly, the NF-кB pathway includes a self-control mechanism that eventually limits inflammation. Toward the end of the response, the expression of genes that promote leukocyte apoptosis or encode anti-inflammatory cytokines commences. It is when the control mechanisms governing NF- $\kappa \mathrm{B}$ signaling malfunction and fail to damp down inflammation, or are insufficient to limit rampant inflammation, that disease may be manifested.
Under steady-state conditions, inflammation does not occur because NF- $\mathrm{KB}$ is prevented from reaching the nucleus and thus accessing the promoters of its target genes. This blockage is mediated by members of the "inhibitor of $\kappa \mathrm{B}$ " (ІкB) family of cytoplasmic inhibitors, which bind to $\mathrm{NF}-\kappa \mathrm{B}$ proteins and sequester them in the cytoplasm. NF$\kappa \mathrm{B}$ activation therefore generally requires the degradation

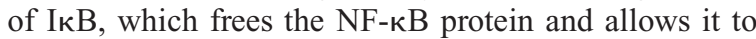
enter the nucleus and initiate transcription. The ubiquitination and subsequent proteasomal degradation of ІкB is triggered by phosphorylation of its $\mathrm{I} \kappa \mathrm{B} \alpha$ subunit, an event mediated by activation of the IкB kinase (IKK) complex. IKK complex activation in turn depends on the CBM complex, which comprises three signaling proteins CARMA1 (caspase recruitment domain-containing protein 11; also known as CARD-containing MAGUK protein 1), BCL10 (B-cell lymphoma/leukemia 10), and MALT1 (mucosa-associated lymphoid tissue [MALT] lymphoma translocation gene 1) (Fig. 1). It is now becoming clear that MALT1 plays more than just a support role during NF- $\mathrm{KB}$ activation and has profound effects on its outcome.

Another molecule recently found to be involved in regulating NF-кB activation is Ariadne-2 (ARIH2). ARIH2 is a member of the RBR family of E3 ligases, a subset of degradative enzymes that are unusual in both their structure and method of extending ubiquitin chains (van der Reijden et al. 1999; Aguilera et al. 2000; Tan et al. 2000; Marin et al. 2004). The prototypical RBR E3 ligase TRIAD3 has been shown to be crucial for TLR degradation and thus the negative regulation of TLR-triggered NF- $\mathrm{BB}$ activation leading to inflammation (Chuang and Ulevitch 2004; Fearns et al. 2006; Nakhaei et al. 2009). ARIH2 was first identified in flies and plants, and the mammalian form has only recently come under study.

It has been known since the 1980s that the body's nervous system and immune system are linked (Levy et al. 
Two pathways to activate NF- $\kappa B$

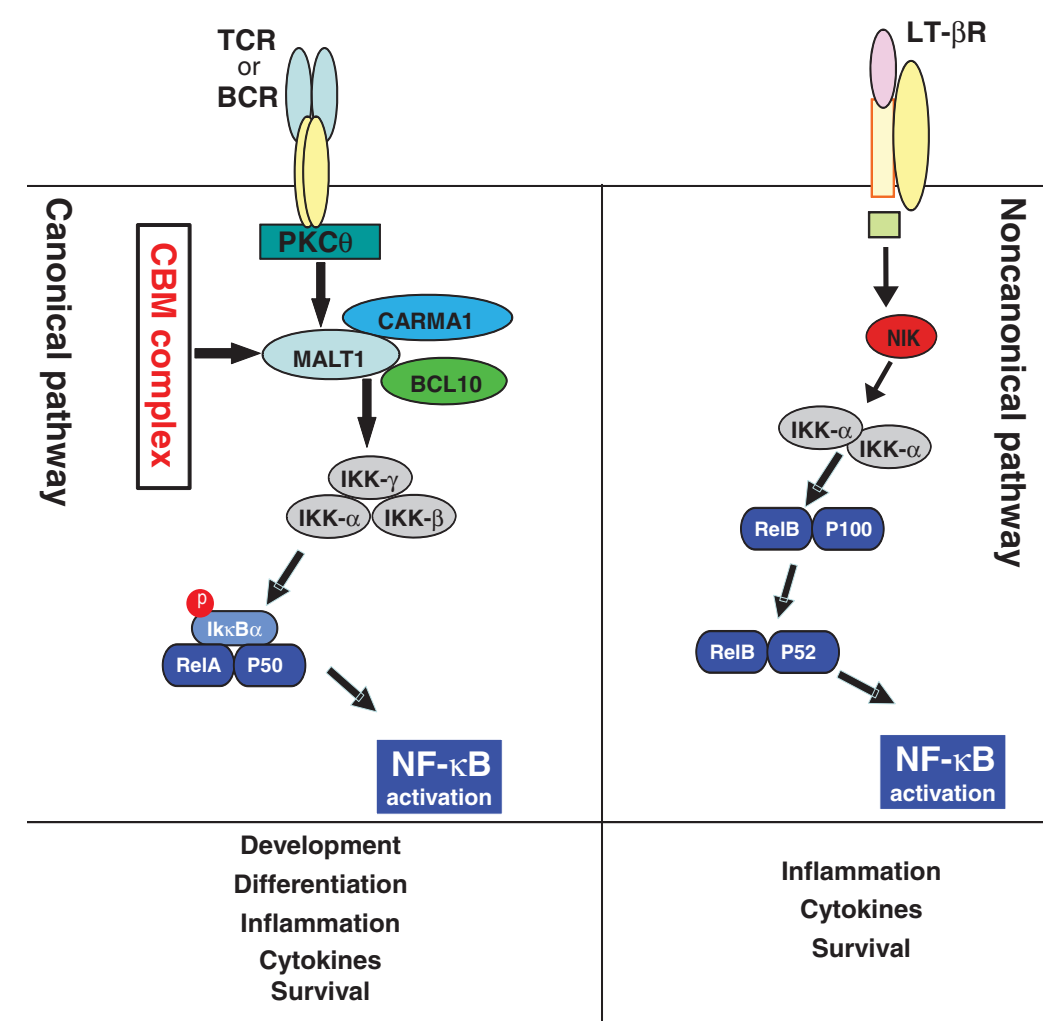

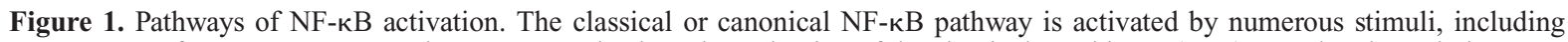
engagement of TCRs or BCRs. Such engagement leads to the activation of the classical IкB kinase (IKK) complex through the CBM complex, which is composed of the three signaling proteins CARMA1, BCL10, and MALT1. IKK complex activation results in phosphorylation of its I $\kappa \mathrm{B} \alpha$ subunit, triggering the ubiquitination and subsequent proteasomal degradation of I $\mathrm{B}$; NF- $\kappa \mathrm{B}$ is then free to enter the nucleus. Activation of the noncanonical NF- $\mathrm{kB}$ pathway leads to the phosphorylation of p100 and its partial proteasomemediated degradation to $\mathrm{p} 52$, a process that is regulated through "NF- $\mathrm{BB}$-inducing kinase" (NIK) and IKK- $\alpha$. In both pathways, transcriptionally active NF- $\mathrm{KB}$ molecules initiate the transcription of specific sets of target genes. The proteins encoded by these genes are involved in cell survival, development, and differentiation, as well as in proinflammatory cytokine production.

$1985 ; 1987)$, but elucidation of the precise connections has lagged. An intriguing circuit exists that involves the vagus nerve and inflammation. The vagus nerve arises in the brain and extends to the visceral organs, establishing a neural circuit that regulates the physiological responses of these tissues to injury, infection, or an altered environment. One of these responses is the suppression of proinflammatory cytokine production, leading to the naming of this circuit as the "inflammatory reflex" (Tracey 2002). It has been shown that electrical stimulation of the vagus nerve can reduce the tissue damage associated with the excessive inflammatory responses underlying sepsis or endotoxemia (Borovikova et al. 2000; Guarini et al. 2003; Huston et al. 2007; 2009). The suppressive signal is delivered when acetylcholine (ACh) released in response to vagus nerve stimulation binds to nicotinic acetylcholine receptors (nAChR) expressed on the surfaces of cytokine-producing splenic cells Accordingly, cholinergic agonists that stimulate the vagus nerve and increase the production of ACh have decreased cytokine production and ameliorated inflammatory disease in animal models (van Westerloo et al. 2006; Giebelen et al. 2007; Pavlov et al. 2007; Yeboah et al. 2008; Kox et al. 2009;
Rosas-Ballina et al. 2009). However, exactly which cell types release ACh and how they participate in the inflammatory reflex has been challenging to dissect.

In this article, we examine the roles of three molecules newly recognized as important for the control of inflammation: MALT1, Ariadne-2, and ACh. We summarize our current state of knowledge of how these molecules function and how they are involved in NF-kB or AChnAChR signaling pathways.

\section{MALT1}

Our laboratory has long been interested in NF-кB signaling in lymphocytes. Our group was one of the first to show that MALT1 is a crucial component of antigen receptor-triggered signaling in T cells (Ruefli-Brasse et al. 2003; Ruland et al. 2003). Using gene-targeted MALT1deficient $\left(\mathrm{MALT1}^{-/-}\right.$) mice, we showed that MALT1 is essential for T-cell activation, proliferation, and IL-2 production in response to TCR ligation and is strictly required for NF- $\kappa \mathrm{B}$ activation induced by TCR engagement (Ruland et al. 2003). We have continued our explorations of MALT1 functions in $\mathrm{T}$ cells and have 
discovered that MALT1 is indispensable for the encephalitogenic potential of IL-17-producing T helper (Th17) cells. The normal function of Th17 cells is to battle certain bacteria and fungi, but uncontrolled activation of this subset results in excessive inflammation and symptoms of autoimmune disease (McGeachy and McSorley 2012) (Fig. 2). In our most recent work, we show that MALT1 $1^{-/-}$mice are resistant to the induction of experimental autoimmune encephalomyelitis (EAE), a well-established mouse model of multiple sclerosis (MS) (Brustle et al. 2012).

A key conundrum in the EAE model has been the identity of the pathogenic $\mathrm{CD} 4^{+} \mathrm{T}$-cell population responsible for the disease symptoms. Historically, Th1 cells were thought to be the culprit, in line with the elevated Th1 cytokines observed in relapsing MS patients (Imam et al. 2007). However, mice lacking IFN- $\gamma$ are more, not less, susceptible to EAE induction (Krakowski and Owens 1996). Subsequent work has established that Th17 cells are in fact the main player in EAE/MS, and that the Th17inducing cytokine IL-23, rather than the Th1-inducing cytokine IL-12, is crucial for EAE induction (Cua et al. 2003). Th17 cells have thus been studied intensively in vitro as well as in vivo in the context of EAE/MS (Langrish et al. 2005; Park et al. 2005; Littman and Rudensky 2010). Examinations in mouse models of the expression of Th17-specific cytokines (IL-23, IL-17, and GM-CSF) and transcription factors (ROR $\gamma t$ and $\operatorname{ROR} \alpha)$ and their impact on EAE have solidified the premise that it is Th17 cells that are the main drivers of EAE/MS (Dardalhon et al. 2008).
The dependence of EAE on both Th17 cells and MALT1 prompted us to examine the properties of MALT1-deficient Th17 cells. We showed that Th17 cells derived from MALT1 $1^{-/-}$mice were still capable of infiltrating the central nervous system but did not cause disease (Brustle et al. 2012). Accordingly, these nonpathogenic $\mathrm{T}$ cells showed a marked decrease in vitro and in vivo in their production of the encephalitogenic cytokines IL-17 and GM-CSF. However, no alterations to the expression of lineage-specific transcription factors were observed. These findings implied that MALT1 ${ }^{-/-}$ mice do not have a defect in Th17 cell differentiation per se, but rather that these cells cannot perform normal Th17 effector functions and so are not encephalitogenic. We then investigated the scaffolding function of MALT1 by examining the differentiation of naïve wild-type (WT) T cells into Th1 or Th17 cells in the presence or absence of the pharmacological inhibitor "Nemo-binding domain" (NBD), which prevents IKK assembly and therefore blocks canonical NF-кB activation (May et al. 2000). We found that Th17-polarized WT Th cells differentiating in the presence of NBD showed a drastic reduction in IL-17 secretion, whereas secretion of IFN- $\gamma$ by Th1-polarized cells differentiating in the presence of NBD was not affected (Brustle et al. 2012). These data indicate that canonical NF-KB activation involving MALT1 is more important for Th17 cells than for Th1 cells (Fig. 3).

In addition to its scaffolding function, MALT1 possesses paracaspase activity that cleaves specific protein substrates to facilitate T-cell activation (Coornaert et al. 2008; Rebeaud et al. 2008; Hailfinger et al. 2011). In contrast to

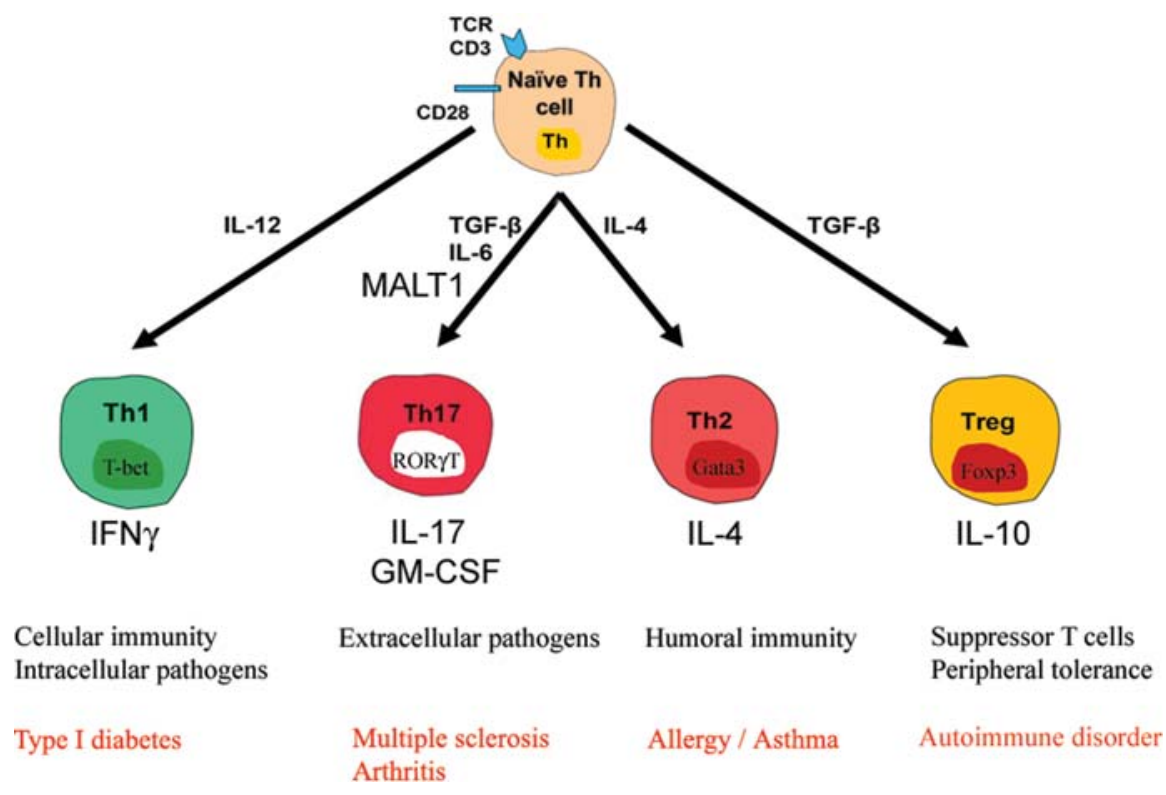

Figure 2. Role of MALT1 in pathways of T helper cell subset differentiation. Naïve T helper (Th) cells that undergo activation because of TCR/CD28 engagement differentiate into distinct effector cell subsets depending on the cytokine milieu. The presence of TGF- $\beta$ plus IL-6 drives the differentiation of Th17 cells, a process that depends on the transcription factor ROR $\gamma t$ and results in the production of IL-17 and GM-CSF. Although these molecules are helpful in combatting certain extracellular pathogens, they also contribute to the inflammation associated with diseases such as MS and arthritis. MALT is critical for this proinflammatory cytokine production. Th17 cells derived from MALT1 ${ }^{-/-}$mice show a marked decrease in IL-17 and GM-CSF production but no alterations to lineage-specific transcription factors. 


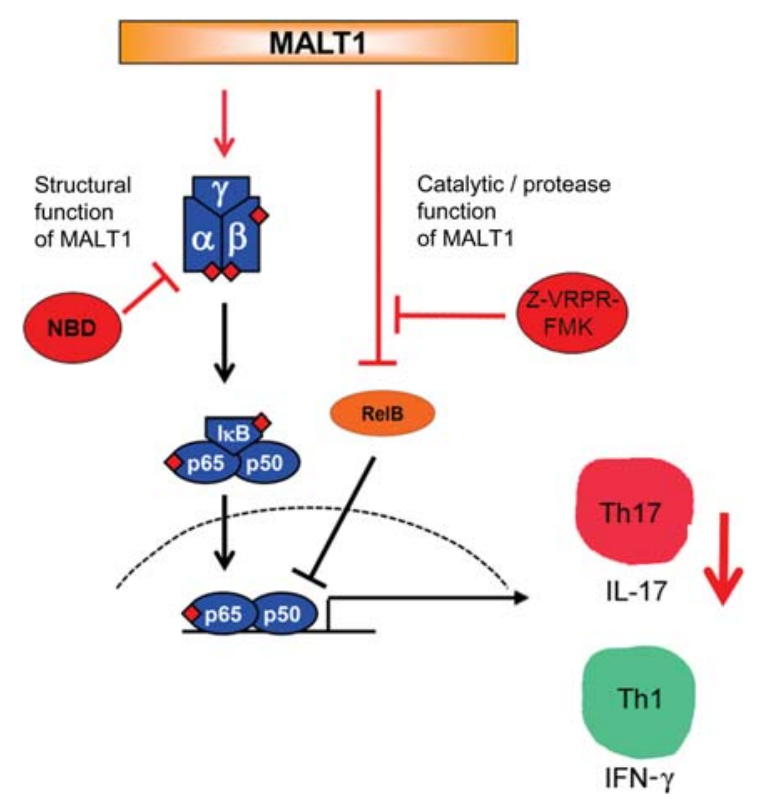

Figure 3. Both canonical NF-KB activation and MALT1 protease activity are crucial for inflammatory cytokine production by activated Th17 cells. MALT1 has both a structural scaffolding function and a catalytic protease function. Treatment of WT T cells with the pharmacological inhibitor NBD, which prevents IKK assembly and therefore blocks canonical NF- $\kappa$ B activation, leads to a drastic reduction in IL-17 secretion. In contrast, NBD has no effect on IFN- $\gamma$ secretion by Th1 cells. Similarly, treatment of WT T cells with the peptide caspase inhibitor Z-VRPRFMK, which inhibits MALT1's paracaspase activity, reduces IL-17 production by Th17 cells but has no impact on IFN- $\gamma$ secretion by Th1 cells.

MALT1's scaffolding function, this protease activity is not crucial for I $\mathrm{I} \mathrm{B} \alpha$ degradation and acts downstream from IKK (Duwel et al. 2009). We showed that inhibition of MALT1's paracaspase activity by the peptide caspase inhibitor Z-VRPR-FMK reduced IL-17 production by Th17-polarized WT Th cells but had no impact on Th1cell differentiation (Fig. 3) (Brustle et al. 2012). Thus, both canonical NF-KB activation and MALT1 protease activity are crucial for the activation of Th17 cells but not Th1 cells. These data further suggest that Th17-cell activation is regulated by two independent pathways that both involve MALT1.

Th1 and Th17 cells can overlap in their cytokine production profiles, a plasticity (ability to convert from one subset to another) that is critical in various mouse and human inflammatory diseases (Lock et al. 2002; Kurschus et al. 2010; Feng et al. 2011; Hirota et al. 2011). We investigated whether Th17/Th1 plasticity was affected by MALT1 deficiency. We injected WT mice with MOG-specific, in vitro-generated Th17 cells derived from WT or MALT1 $1^{-/-}$mice and determined the frequencies of Th1 and Th17 cells in these animals 18 days later. In mice receiving WT Th17 cells, a small population of Th cells producing both IFN- $\gamma$ and IL-17 was detected, indicative of Th17/Th1 plasticity (Brustle et al. 2012). In contrast, in mice receiving MALT $1^{-/-}$Th17 cells, no Th cells with the capacity to produce both IFN- $\gamma$ and IL-17 were observed, and only a few Th cells able to produce IFN- $\gamma$ alone were detected. This lack of double IFN- $\gamma /$ IL17 producers in the absence of MALT1 suggests a defect in Th1/Th17 plasticity that could explain the inability of MOG-specific MALT1 ${ }^{-/-}$Th17 cells to cause EAE in WT mice. Hirota et al. have shown using a fate-mapping system for IL-17-producing cells that almost all IFN- $\gamma$ producing cells in the spinal cords of mice with severe EAE were formerly Th17 cells (Hirota et al. 2011). However, we have found comparable levels of IFN- $\gamma$ producers in the brains and spinal cords of WT and MALT1 ${ }^{-/-}$ mice subjected to EAE induction, even though Th17 cells are missing in MALT1 $1^{-/-}$mice and these animals do not develop EAE. These data suggest that MALT1 ${ }^{-/}-\mathrm{T}$ cells are capable of differentiating normally into Th1 cells (but not Th17 cells) during EAE induction.

Many different mechanisms by which Th17 cells could be converted into Th1 cells have been proposed in the literature (Coomes et al. 2013). These mechanisms include not only T-cell-intrinsic factors such as microRNAs, transcription factor regulation, and epigenetic modifications but also extrinsic factors such as accessory innate leukocytes, the cytokine microenvironment, receptor regulation, and metabolic pathways. An example of an intrinsic conversion factor is the up-regulation of T-bet, the Th1-specific transcription factor that drives IFN- $\gamma$ production and blocks IL-17 expression (Mathur et al. 2006). Another example that involves both intrinsic and extrinsic factors is the production by Th17 cells of IL17A. In a colitis model, IL-17A treatment induced IL-12 production by innate leukocytes and therefore facilitated the conversion of Th17 cells into Th1 cells (Feng et al. 2011). The surrounding microenvironment alone can sometimes promote the generation or conversion of Th1 cells. For example, nitric oxide production by macrophages induces the expression of IL-12R $\beta$ on $T$ cells and therefore favors Th1 differentiation (Niedbala et al. 1999). Nevertheless, our MALT1 ${ }^{-/-}$Th17 cells did not convert into Th1 cells even in a WT microenvironment. The reason for this lack of plasticity remains unknown, as the transcriptional profile of MALT $1^{-/-} \mathrm{T}$ cells is not abnormal (Brustle et al. 2012). Our laboratory continues to investigate the properties of MALT1 and its perhaps surprisingly broad regulatory influence on inflammation.

\section{ARIADNE-2}

Our group recently collaborated with that of Dr. Marc Pellegrini of the Walter and Eliza Hall Institute to determine the physiological function of ARIH2 in mammals. We generated ARIH2-deficient $\left(\mathrm{ARIH} 2^{-/-}\right.$) mice and found that only $3 \%$ of progeny on a mixed genetic background were able to avoid embryonic lethality (Lin et al. 2013). Although these animals survived beyond weaning, they died soon after reaching maturity because of massive multiorgan inflammation. To determine which pathway underlay this inflammation, we crossed $\mathrm{ARIH} 2^{-/-}$ mice to animals lacking the TLR signaling adaptor MyD88. Combined deficiency of ARIH2 and MyD88 
(but not IFN- $\gamma$ or TNF) delayed but did not prevent death (Lin et al. 2013). These data implicated TLR-MyD88 signaling in the fatal inflammation killing $\mathrm{ARIH} 2^{-/-}$ mice.

To circumvent the early lethality of $\mathrm{ARIH} 2^{-/-}$mice, we constructed chimeric animals bearing ARIH $2^{-/-}$hematopoietic cells. These mice once again developed severe inflammation characterized by high levels of serum proinflammatory cytokines and immunoglobulins. Lymphoid organs showed prominent infiltration by granulocytes, macrophages, and DCs, and other organs showed infiltration by $\mathrm{T}$ cells and myeloid cells. Subsequent examination of isolated leukocyte subsets revealed that ARIH2 $2^{-/-} \mathrm{T}$ cells and B cells did not have any intrinsic signaling defects. Although regulatory T-cell numbers were increased in ARIH2-deficient chimeras, these cells showed a normal capacity to inhibit responses of conventional effector T cells (Lin et al. 2013). Thus, the runaway inflammation in $\mathrm{ARIH} 2^{-/-}$mice and chimeras was not due to a T-cell defect.

Examination of DCs isolated from $\mathrm{ARIH} 2^{-/-}$mice established that ARIH2 plays no role in DC generation or differentiation, at least at the early stages. However, $\mathrm{ARIH} 2^{-/-}$DCs showed greater surface concentrations of MHC class II and T-cell costimulatory molecules and spontaneously produced high levels of proinflammatory cytokines, including IL-6, IL-12, and TNF. In collaboration with Dr. Pamela Ohashi's group of the Campbell Family Institute for Breast Cancer Research, we investigated whether ARIH2 $2^{-/-}$DCs could induce diabetes in the RIP-GP system (Ohashi et al. 1991; Oldstone et al. 1991). In RIP-GP mice, disease induction depends on DC maturation typically triggered by prior addition of a TLR ligand. Surprisingly, ARIH2 $2^{-/-}$DCs successfully induced diabetes in all mice tested in the absence of any TLR ligand, indicating that these cells had spontaneously become activated and had matured enough to activate autoreactive $\mathrm{T}$ cells. Furthermore, the transfer of $\mathrm{ARIH} 2^{-/-}$DCs alone into WT mice resulted in the rapid death of these animals due to excessive inflammation (Lin et al. 2013). These results indicated that ARIH2 is a crucial negative regulator of the inflammatory response.

Our next set of experiments explored signaling pathways in ARIH2 $2^{-/-}$DCs. NF- $\kappa$ B signaling was found to be hyperactivated and sustained in these cells. Previous reports have established that, in contrast to the suppressive effects of cytoplasmic IкB, a nuclear hypophosphorylated form of the I $\mathrm{I} B \beta$ subunit of I $\mathrm{KB}$ can bind to and activate nuclear $\mathrm{p} 65$, promoting NF- $\mathrm{B}$ signaling (Suyang et al. 1996; Rao et al. 2010; Scheibel et al. 2010). This signaling in turn leads to proinflammatory cytokine production. Our investigations revealed that ARIH2 physically binds to newly synthesized nuclear hypophosphorylated IкB $\beta$ and facilitates its ubiquitination and proteasomal degradation, thereby decreasing

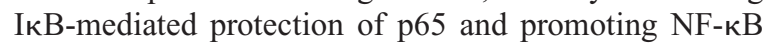
activation. In the absence of ARIH2, the unrestrained NF- $\kappa \mathrm{B}$ signaling in DCs leads to their spontaneous maturation and consequently uncontrolled inflammation (Lin et al. 2013). Thus, ARIH2 is a novel and essential regu- lator of DC maturation and activation that is required to regulate the inflammatory response.

ARIH2 may be an attractive therapeutic target for drugs intended to reduce inflammation or autoimmune symptoms because the structure of this E3 ligase is comparatively unusual. An agonist that could increase ARIH2 activity and thus damp down DC activation and inflammation might have little effect on other E3 ligases essential for normal homeostasis. Such drugs could represent a boon for those suffering from immune hypersensitivities or autoimmune disease symptoms. Conversely, antagonists of ARIH2 could stimulate DC activity in situations where it might be beneficial, such as in conjunction with administration of an anticancer vaccine or where a patient is battling a persistent infection. We continue to investigate the properties of this novel inflammatory regulator with these goals in mind.

\section{ACETYLCHOLINE}

As noted above, it was known as early as the mid-1980s that a neural circuit existed in which vagal nerve fibers were connected to the splenic nerve enervating the spleen (Levy et al. 1985; 1987). Electrical stimulation of this circuit resulted in the release of $\mathrm{ACh}$ that shut down TNF production, reducing inflammation. However, it was unclear exactly which cells were the source of this ACh. Subsequent work revealed that lymphocytes could produce ACh (Kawashima et al. 1989; Rinner and Schauenstein 1993), a result we have capitalized on to determine whether the T and B cells in the white pulp of mouse spleen could produce sufficient ACh to suppress inflammation. In collaboration with Dr. Kevin Tracy's group, we used nude mice, which lack functional T cells, and showed that vagal nerve stimulation in these mutant animals did not reduce TNF production in response to endotoxin injection, in contrast to endotoxin-injected WT mice (Rosas-Ballina et al. 2009). Examinations of reporter mice expressing EGFP under the control of the promoter of the gene encoding choline acetyltransferase (ChAT), the enzyme that synthesizes ACh, showed that ACh was produced by only a small subset of $\mathrm{CD}^{+} \mathrm{T}$ cells ( $\sim 4 \%$ of the total) bearing a memory surface marker phenotype. Furthermore, ChAT expression and ACh release were increased if these particular T cells were activated by anti-CD3 antibody (Rosas-Ballina et al. 2009).

Immunofluorescence analyses confirmed that AChproducing $\mathrm{T}$ cells were located in areas of the splenic white pulp bearing nerve endings, and that these nerve endings were incapable of ChAT expression themselves. Importantly, the neural synapse glycoprotein synaptophysin was found to be localized next to ChAT-EGFP ${ }^{+}$ $T$ cells in the white pulp. In addition, these $T$ cells expressed mRNAs encoding the $\beta_{1}$ - and $\beta_{2}$-adrenergic receptors, which have been shown to transduce splenic nerve signaling (Feldman et al. 1987; Kohm and Sanders 2001; Riether et al. 2011).

To test in vivo the validity of our hypothesis that the inflammatory reflex depends on ACh-producing splenic 
$\mathrm{T}$ cells, we transferred the appropriate ChAT-EGFP ${ }^{+}$ $\mathrm{CD}^{+}{ }^{+}$T-cell population (or control ChAT-EGFP ${ }^{-}$ $\mathrm{CD}^{+}{ }^{+} \mathrm{T}$ cells) into nude mice, treated the animals with endotoxin, and stimulated the vagus nerve. Only mice bearing $\mathrm{T}$ cells capable of ChAT expression were able to activate the inflammatory reflex and suppress serum TNF production. Moreover, the adoptively transferred $\mathrm{T}$ cells migrated to the splenic white pulp and took up residence near splenic neurons known to respond to vagus nerve stimulation (Rosas-Ballina et al. 2009).

We confirmed that the effects we observed were indeed dependent on ChAT by using specific siRNA to "knock down" expression of ChAT in splenic $\mathrm{CD}^{+} \mathrm{T}$ cells. These T cells (or control $\mathrm{T}$ cells treated with scrambled siRNA) were adoptively transferred into nude mice, which were then subjected to endotoxin injection and vagus nerve stimulation. We found that mice with reduced ChAT expression were unable to invoke the inflammatory reflex and could not suppress TNF production (RosasBallina et al. 2009). Thus, the ACh produced by splenic memory $\mathrm{T}$ cells is a novel regulator of inflammation, and manipulation of this neural circuit may yield therapeutic benefits. We continue to examine other secondary lymphoid tissues for the presence of ACh-producing T cells as well as nerve endings that may govern their responses to various stimuli.

\section{CONCLUSION}

Uncontrolled inflammation is a feature of many serious human disorders, and the pinpointing of molecules that can reduce inflammation is an important pursuit of modern biomedicine. We are hopeful that our identification of MALT1, ARIH2, and T-cell-produced ACh as regulators of inflammatory signaling will contribute to the design of new anti-inflammatory therapies.

\section{ACKNOWLEDGMENTS}

This work was supported by grants from the Terry Fox Cancer Foundation and the Canadian Institutes of Health Research to T.W.M.

\section{REFERENCES}

Aguilera M, Oliveros M, Martinez-Padron M, Barbas JA, Ferrus A. 2000. Ariadne-1: A vital Drosophila gene is required in development and defines a new conserved family of ringfinger proteins. Genetics 155: 1231-1244.

Borovikova LV, Ivanova S, Zhang M, Yang H, Botchkina GI, Watkins LR, Wang H, Abumrad N, Eaton JW, Tracey KJ. 2000. Vagus nerve stimulation attenuates the systemic inflammatory response to endotoxin. Nature 405: 458-462.

Brustle A, Brenner D, Knobbe CB, Lang PA, Virtanen C, Hershenfield BM, Reardon C, Lacher SM, Ruland J, Ohashi PS, et al. 2012. The NF- $\mathrm{B}$ regulator MALT1 determines the encephalitogenic potential of Th17 cells. J Clin Invest 122: 4698-4709.

Chuang TH, Ulevitch RJ. 2004. Triad3A, an E3 ubiquitin-protein ligase regulating Toll-like receptors. Nat Immunol 5: 495-502.
Coomes SM, Pelly VS, Wilson MS. 2013. Plasticity within the $\alpha \beta^{+} \mathrm{CD} 4^{+} \mathrm{T}$-cell lineage: When, how and what for? Open Biol 3: 120157.

Coornaert B, Baens M, Heyninck K, Bekaert T, Haegman M, Staal J, Sun L, Chen ZJ, Marynen P, Beyaert R. 2008. T cell antigen receptor stimulation induces MALT1 paracaspasemediated cleavage of the NF- $\mathrm{B}$ inhibitor A20. Nat Immunol 9: $263-271$.

Cua DJ, Sherlock J, Chen Y, Murphy CA, Joyce B, Seymour B, Lucian L, To W, Kwan S, Churakova T, et al. 2003. Interleukin-23 rather than interleukin-12 is the critical cytokine for autoimmune inflammation of the brain. Nature 421: 744-748.

Dardalhon V, Korn T, Kuchroo VK, Anderson AC. 2008. Role of Th1 and Th17 cells in organ-specific autoimmunity. J Autoimmun 31: 252-256.

Duwel M, Welteke V, Oeckinghaus A, Baens M, Kloo B, Ferch U, Darnay BG, Ruland J, Marynen P, Krappmann D. 2009. A20 negatively regulates T cell receptor signaling to NF- $\mathrm{kB}$ by cleaving Malt1 ubiquitin chains. J Immunol 182: $7718-$ 7728.

Fearns C, Pan Q, Mathison JC, Chuang TH. 2006. Triad3A regulates ubiquitination and proteasomal degradation of RIP1 following disruption of Hsp90 binding. J Biol Chem 281: $34592-34600$.

Feldman RD, Hunninghake GW, McArdle WL. 1987. $\beta$-Adrenergic-receptor-mediated suppression of interleukin 2 receptors in human lymphocytes. J Immunol 139: 3355-3359.

Feng T, Qin H, Wang L, Benveniste EN, Elson CO, Cong Y. 2011. Th17 cells induce colitis and promote Th1 cell responses through IL-17 induction of innate IL-12 and IL-23 production. J Immunol 186: 6313-6318.

Gasparini C, Feldmann M. 2012. NF-кB as a target for modulating inflammatory responses. Curr Pharm Des 18: 57355745.

Giebelen IA, van Westerloo DJ, LaRosa GJ, de Vos AF, van der Poll T. 2007. Local stimulation of $\alpha 7$ cholinergic receptors inhibits LPS-induced TNF- $\alpha$ release in the mouse lung. Shock 28: $700-703$.

Guarini S, Altavilla D, Cainazzo MM, Giuliani D, Bigiani A, Marini H, Squadrito G, Minutoli L, Bertolini A, Marini R, et al. 2003. Efferent vagal fibre stimulation blunts nuclear factor- $\kappa \mathrm{B}$ activation and protects against hypovolemic hemorrhagic shock. Circulation 107: 1189-1194.

Hailfinger S, Nogai H, Pelzer C, Jaworski M, Cabalzar K, Charton JE, Guzzardi M, Decaillet C, Grau M, Dorken B, et al. 2011. Malt1-dependent RelB cleavage promotes canonical NF- $\mathrm{KB}$ activation in lymphocytes and lymphoma cell lines. Proc Natl Acad Sci 108: 14596-14601.

Hirota K, Duarte JH, Veldhoen M, Hornsby E, Li Y, Cua DJ, Ahlfors H, Wilhelm C, Tolaini M, Menzel U, et al. 2011. Fate mapping of IL-17-producing T cells in inflammatory responses. Nat Immunol 12: 255-263.

Huston JM, Gallowitsch-Puerta M, Ochani M, Ochani K, Yuan R, Rosas-Ballina M, Ashok M, Goldstein RS, Chavan S, Pavlov VA, et al. 2007. Transcutaneous vagus nerve stimulation reduces serum high mobility group box 1 levels and improves survival in murine sepsis. Crit Care Med 35: 2762-2768.

Huston JM, Rosas-Ballina M, Xue X, Dowling O, Ochani K, Ochani M, Yeboah MM, Chatterjee PK, Tracey KJ, Metz CN. 2009. Cholinergic neural signals to the spleen down-regulate leukocyte trafficking via CD11b. J Immunol 183: 552559.

Imam SA, Guyton MK, Haque A, Vandenbark A, Tyor WR, Ray SK, Banik NL. 2007. Increased calpain correlates with Th1 cytokine profile in PBMCs from MS patients. J Neuroimmunol 190: 139-145.

Kawashima K, Oohata H, Fujimoto K, Suzuki T. 1989. Extraneuronal localization of acetylcholine and its release upon nicotinic stimulation in rabbits. Neurosci Lett 104: 336-339.

Kohm AP, Sanders VM. 2001. Norepinephrine and $\beta_{2}$-adrenergic receptor stimulation regulate $\mathrm{CD} 4^{+} \mathrm{T}$ and $\mathrm{B}$ lymphocyte function in vitro and in vivo. Pharmacol Rev 53: 487-525. 
Kox M, van Velzen JF, Pompe JC, Hoedemaekers CW, van der Hoeven JG, Pickkers P. 2009. GTS-21 inhibits pro-inflammatory cytokine release independent of the Toll-like receptor stimulated via a transcriptional mechanism involving JAK2 activation. Biochem Pharmacol 78: 863-872.

Krakowski M, Owens T. 1996. Interferon- $\gamma$ confers resistance to experimental allergic encephalomyelitis. Eur J Immunol 26: $1641-1646$.

Kurschus FC, Croxford AL, Heinen AP, Wortge S, Ielo D, Waisman A. 2010. Genetic proof for the transient nature of the Th17 phenotype. Eur J Immunol 40: 3336-3346.

Langrish CL, Chen Y, Blumenschein WM, Mattson J, Basham B, Sedgwick JD, McClanahan T, Kastelein RA, Cua DJ. 2005. IL-23 drives a pathogenic T cell population that induces autoimmune inflammation. $J$ Exp Med 201: 233-240.

Levy SM, Herberman RB, Maluish AM, Schlien B, Lippman M. 1985. Prognostic risk assessment in primary breast cancer by behavioral and immunological parameters. Health Psychol 4: 99-113.

Levy S, Herberman R, Lippman M, d'Angelo T. 1987. Correlation of stress factors with sustained depression of natural killer cell activity and predicted prognosis in patients with breast cancer. J Clin Oncol 5: 348-353.

Lin AE, Ebert G, Ow Y, Preston SP, Toe JG, Cooney JP, Scott HW, Sasaki M, Saibil SD, Dissanayake D, et al. 2013. ARIH2 is essential for embryogenesis, and its hematopoietic deficiency causes lethal activation of the immune system. Nat Immunol 14: 27-33.

Littman DR, Rudensky AY. 2010. Th17 and regulatory T cells in mediating and restraining inflammation. Cell 140: 845-858.

Lock C, Hermans G, Pedotti R, Brendolan A, Schadt E, Garren H, Langer-Gould A, Strober S, Cannella B, Allard J, et al. 2002. Gene-microarray analysis of multiple sclerosis lesions yields new targets validated in autoimmune encephalomyelitis. Nat Med 8: 500-508.

Marin I, Lucas JI, Gradilla AC, Ferrus A. 2004. Parkin and relatives: The RBR family of ubiquitin ligases. Physiol Genomics 17: 253-263.

Mathur AN, Chang HC, Zisoulis DG, Kapur R, Belladonna ML, Kansas GS, Kaplan MH. 2006. T-bet is a critical determinant in the instability of the IL-17-secreting T-helper phenotype. Blood 108: 1595-1601.

May MJ, D'Acquisto F, Madge LA, Glockner J, Pober JS, Ghosh S. 2000. Selective inhibition of NF- $\kappa$ B activation by a peptide that blocks the interaction of NEMO with the IкB kinase complex. Science 289: 1550-1554.

McGeachy MJ, McSorley SJ. 2012. Microbial-induced Th17: Superhero or supervillain? J Immunol 189: 3285-3291.

Nakhaei P, Mesplede T, Solis M, Sun Q, Zhao T, Yang L, Chuang TH, Ware CF, Lin R, Hiscott J. 2009. The E3 ubiquitin ligase Triad3A negatively regulates the RIG-I/MAVS signaling pathway by targeting TRAF3 for degradation. PLoS Pathog 5: e1000650.

Niedbala W, Wei XQ, Piedrafita D, Xu D, Liew FY. 1999. Effects of nitric oxide on the induction and differentiation of Th1 cells. Eur J Immunol 29: 2498-2505.

Ohashi PS, Oehen S, Buerki K, Pircher H, Ohashi CT, Odermatt B, Malissen B, Zinkernagel RM, Hengartner H. 1991. Ablation of "tolerance" and induction of diabetes by virus infection in viral antigen transgenic mice. Cell 65: 305-317.

Oldstone MB, Nerenberg M, Southern P, Price J, Lewicki H. 1991. Virus infection triggers insulin-dependent diabetes mellitus in a transgenic model: Role of anti-self (virus) immune response. Cell 65: 319-331.

Park H, Li Z, Yang XO, Chang SH, Nurieva R, Wang YH, Wang Y, Hood L, Zhu Z, Tian Q, et al. 2005. A distinct lineage of $\mathrm{CD} 4 \mathrm{~T}$ cells regulates tissue inflammation by producing interleukin 17. Nat Immunol 6: 1133-1141.

Pavlov VA, Ochani M, Yang LH, Gallowitsch-Puerta M, Ochani K, Lin X, Levi J, Parrish WR, Rosas-Ballina M, Czura CJ, et al. 2007. Selective $\alpha$ 7-nicotinic acetylcholine receptor agonist GTS-21 improves survival in murine endotoxemia and severe sepsis. Crit Care Med 35: 1139-1144.

Rao P, Hayden MS, Long M, Scott ML, West AP, Zhang D, Oeckinghaus A, Lynch C, Hoffmann A, Baltimore D, et al. 2010. IкB $\beta$ acts to inhibit and activate gene expression during the inflammatory response. Nature 466: 1115-1119.

Rebeaud F, Hailfinger S, Posevitz-Fejfar A, Tapernoux M, Moser R, Rueda D, Gaide O, Guzzardi M, Iancu EM, Rufer $\mathrm{N}$, et al. 2008. The proteolytic activity of the paracaspase MALT1 is key in T cell activation. Nat Immunol 9: 272-281.

Riether C, Kavelaars A, Wirth T, Pacheco-Lopez G, Doenlen R, Willemen H, Heijnen CJ, Schedlowski M, Engler H. 2011. Stimulation of $\beta_{2}$-adrenergic receptors inhibits calcineurin activity in $\mathrm{CD}^{+}$T cells via PKA-AKAP interaction. Brain Behav Immun 25: 59-66.

Rinner I, Schauenstein K. 1993. Detection of choline-acetyltransferase activity in lymphocytes. J Neurosci Res 35: 188191.

Rosas-Ballina M, Goldstein RS, Gallowitsch-Puerta M, Yang L, Valdes-Ferrer SI, Patel NB, Chavan S, Al-Abed Y, Yang H, Tracey KJ. 2009. The selective $\alpha 7$ agonist GTS-21 attenuates cytokine production in human whole blood and human monocytes activated by ligands for TLR2, TLR3, TLR4, TLR9, and RAGE. Mol Med 15: 195-202.

Ruefli-Brasse AA, French DM, Dixit VM. 2003. Regulation of NF-кB-dependent lymphocyte activation and development by paracaspase. Science 302: $1581-1584$.

Ruland J, Duncan GS, Wakeham A, Mak TW. 2003. Differential requirement for Malt1 in T and B cell antigen receptor signaling. Immunity 19: 749-758.

Scheibel M, Klein B, Merkle H, Schulz M, Fritsch R, Greten FR, Arkan MC, Schneider G, Schmid RM. 2010. IкBß is an essential co-activator for LPS-induced IL-1 $\beta$ transcription in vivo. J Exp Med 207: 2621-2630.

Suyang H, Phillips R, Douglas I, Ghosh S. 1996. Role of unphosphorylated, newly synthesized Iк B $\beta$ in persistent activation of NF-кB. Mol Cell Biol 16: 5444-5449.

Tan NG, Ardley HC, Rose SA, Leek JP, Markham AF, Robinson PA. 2000. Characterisation of the human and mouse orthologues of the Drosophila ariadne gene. Cytogenet Cell Genet 90: $242-245$.

Tracey KJ. 2002. The inflammatory reflex. Nature 420: 853859.

van der Reijden BA, Erpelinck-Verschueren CA, Lowenberg B, Jansen JH. 1999. TRIADs: A new class of proteins with a novel cysteine-rich signature. Protein Sci 8: 1557-1561.

van Westerloo DJ, Giebelen IA, Florquin S, Bruno MJ, Larosa GJ, Ulloa L, Tracey KJ, van der Poll T. 2006. The vagus nerve and nicotinic receptors modulate experimental pancreatitis severity in mice. Gastroenterology 130: 1822-1830.

Yeboah MM, Xue X, Duan B, Ochani M, Tracey KJ, Susin M, Metz CN. 2008. Cholinergic agonists attenuate renal ischemia-reperfusion injury in rats. Kidney Int 74: 62-69. 


\section{$\$_{\text {CSH }}^{\infty}$ Cold Spring Harbor Symposia SYMPOSIA On Quantitative Biology}

\section{Dissection of Signaling in Inflammation: Three Novel Inflammatory Regulators}

Thorsten Berger, Mary E. Saunders and Tak W. Mak

Cold Spring Harb Symp Quant Biol 2013 78: 141-147 originally published online November 15, 2013

Access the most recent version at doi:10.1101/sqb.78.020107

References This article cites 55 articles, 17 of which can be accessed free at: http://symposium.cshlp.org/content/78/141.full.html\#ref-list-1

\section{License}

Email Alerting Receive free email alerts when new articles cite this article - sign up in Service the box at the top right corner of the article or click here. 